\title{
E o Verbo se fez Carne: \\ Por uma Performatividade da Palavra no Teatro Contemporâneo Brasileiro
}

\begin{abstract}
Resumo
Esse artigo tem como objetivo explicitar características recorrentes na dramaturgia contemporânea e as suas relações com a materialidade cênica. Partindo de um breve percurso histórico, acerca dos modos de utilização da palavra na composição de importantes dramaturgos do teatro ocidental, ele discorre sobre aspectos performativos do texto teatral e reflete sobre a utilização deste elemento no teatro contemporâneo. Para tanto, como objeto de exemplificação, tem-se a encenação e a dramaturgia de Congresso Internacional do Medo do grupo Espanca!.
\end{abstract}

Palavras-chave: dramaturgia textualidade - Espanca! - teatro contemporâneo

\section{*Nina Caetano ** Phelippe Celestino}

keywords: dramaturgy - textuality Espanca! - contemporary theater 
Escrever não é certamente impor uma forma 'de expressão' a uma matéria vivida A literatura está antes do lado do informe' ou do inacabamento (...). Escrever é um caso de devir' sempre inacabado, sempre em via de fazer'se' e que extravasa qualquer matéria vivivel ou vivida. É um processo' ou seja' uma passagem de Vida que atravessa o vivivel e o vivido A escrita é inseparável do devir: ao escrever' estamos num devir'mulher' num devir'animal ou vegetal' num devir'molécula' até num devir'imper ceptivel. (DELEUZE, 1997)

Assim como a morte, é certo que a supremacia do texto no, e sobre o teatro, deixou de ser fundamento imprescindível às práticas contemporâneas brasileiras de criação cênica. Assim, tendo sido a tradição textocêntrica destituída de seu esplendor, podemos perguntar: qual status a relação texto-cena atingiu contemporaneamente?

O textocentrismo esmarrido artistas passam a se organizar coletivamente, suprimindo radicalmente a presença dos antigos demiurgos, a saber, o autor dramático e o encenador ${ }^{1}$. Dessa maneira, artistas se reúnem e buscam criar um discurso próprio, que friccione texto e cena. Esse projeto certamente "se conecta com a necessidade do teatro de grupo em dizer a sua cena" (SCHETTINI, 2009, p.80), e não mais ao discurso único e particular, seja ele advindo de um autor dramático ou de um encenador.

No teatro de grupo' notamos que' geralmente' não há a suposta importância atribuída ao autor ou encenador teatral A intenção das companhias é que se compartilhe a autoria da obra cênica Nota se que o processo de criação conjunta não se traduz' obrigatoriamente' na suspensão da escrita dramática' porém questiona'se o lugar do autor como artista autônomo que tem um status privilegiado no processo de criação cênica (...). (FISCHER, ${ }^{2003,} p^{.166)}$

Sem precedentes históricos brasileiros ${ }^{2}$, desde a segunda metade do século passado tais organizações artísticas vêm proliferando dentro da nossa prática cênica, e possuem como aspecto essencial um princípio matriz: a valorização do calor inventivo das salas de ensaio - ou melhor, o foco no processo. Um denominador comum a tais coletivos é o que se convencionou chamar de teatro de grupo. Esse conceito se tornou fundamental para inúmeras pesquisas que estudam o contexto teatral contemporâneo brasileiro ${ }^{3}$.

O teatro de grupo vem se caracterizando como um modo de produção cênica recorrente no Brasil desde o século XX. e leva às últimas consequências a escolha que determinados artistas fazem pelo trabalho perene e sensivel gerado na coletividade Não são poucos os grupos de teatro que tem se destacado no cenário teatral brasileiro como vigorosas fontes de pesquisa e experimentação da cena. Basta citar os exemplos mais conhecidos para perceber a relevância que o trabalho do teatro de grupo tem para o teatro nacional: Grupo Galpão' Grupo Oi Nóis Aqui Traveiz' Grupo Imbuaça' Cia'dos Atores' Cia do Latão' entre tantos outros que tem como pioneiros as experiências de grupos como o Arena' o Oficina e o Opinião. (SCHETTINI, 2009, $p$. 12)

Como resultado, grande parte organiza-se numa dinâmica que envolve todo o coletivo criador no processo de criação da cena, compartilhando assim a autoria da obra. Consequentemente, dramaturgos, figurinistas, cenógrafos e iluminadores, que antes se encerravam em seus ateliês e estúdios reservados, hoje mergulham na imensidão estelar inerente à sala de ensaio ${ }^{4}$.

Por outro lado, até mesmo aquelas práticas que ainda se propõem a ter o texto como único ponto de partida, uma hora ou outra, interveem no texto, ou alterando uma rubrica, ou invertendo uma fala, ou cortando um diálogo, ou excluindo uma personagem. Ou seja: os diversos artistas envolvidos na criação, a saber, atores, encenador, figurinistas, cenógrafos, sonoplastas e afins, não compreendem mais o texto como "objeto sagrado",

\footnotetext{
Para saber mais acerca desse processo histórico que envolve a presença do textocentrismo e da hegemonia do encenador no teatro, ver ROUBINE, Jean-Jacques. Ä linguagem da encenaçấo teatral. Rio de Janeiro: Zahar Editores, 1982.

2 Enfatiza-se o contexto brasileiro devido ao fato de ter existido na Idade Média a prática desenvolvida pela Commedia dell'arte, que, consistia numa modalidade teatral organizada de maneira artesanal e coletiva, que criava sua cena na fricção entre arte e vida. "E, portanto, pertinente dizer que neste contexto se começou a forjar novos conceitos de organização hegemonia do encenador no teatro, ver ROUBINE, Jean-Jacques. A linguagem da encenação teatral. Rio de Janeiro: Zahar Editores, 1982.

3 Como exemplo de pesquisa envolvendo teatros de grupo podemos citar FERNANDES, Silvia. Grupos teatrais - anos 70 . Campinas: Editora da Unicamp, 2000.

4 Acerca dessa dinâmica referente à criação teatral ver ARAÚJO, Antônio. A encenação no coletivo: desterritorializações da função do diretor no processo colaborativo (tese de doutorado). São Paulo: Universidade de São Paulo, 2008.
} 
intocável. Tal postura, inteiramente independente e autônoma em relação ao texto, acentua-se ainda mais quando nos referimos ao nosso contexto brasileiro, tendo em vista que em nossa trajetória teatral jamais houve - como no Velho Continente - uma tradição textocêntrica que enrijecesse e condicionasse os músculos criativos do fazer teatral. Segundo o diretor brasileiro Walter Lima Torres:

O teatro' durante muito tempo' foi alocado numa categoria da literatura' como gênero literário dramático Entretanto' o teatro excede a sua condição literária. E' hoje' sabe-se que o teatro não é literatura' é efetivamente teatro' e como tal se define por meio de uma prática cênica· TORRES, ${ }^{2001,}$ $p^{.64)}$

Todavia, não devemos confundir alhos com bugalhos. O texto como eixo condensador da autoria e criação teatral não incorre necessariamente no fato de que a palavra, ou seja, o verbo; tenha sido a chave para essa soberania. Nessa perspectiva, devemos assinalar ainda uma ocorrência histórica primordial para tal hegemonia, a saber, o teatro como representação e afirmação do discurso e poder ${ }^{5}$ de uma classe social e econômica específica: a burguesia.

Uma vez destituída a hegemonia monárquica, e estabelecida a representatividade burguesa, a Europa do século XVIII observa nascer o embrião do que se tornaria mais à frente o espírito reverenciado até o final do século XIX: o Drama. Assim, o teatro da Antiguidade - permeado por assuntos inerentes à pólis e a sua cultura político-social - e do Renascimento - composto por manifestações preponderantemente populares e públicas - são engolidos pela ficcionalidade íntima das famílias tradicionais lideradas por banqueiros e burocratas, ambos emergentes da Revolução Francesa, e que possuem como gênio comum um fator: o "potencial político e econômico através da destruição da rígida sociedade feudal hierarquizada: porém, essa liberação se dá sob um controle rígido de classe, na perspectiva da acumulação de riqueza através da exploração" (OLIVEIRA, 2013, p. 17). Dessa forma, os ideais de Liberdade, Fraternidade e Igualdade, "profetizados" por Napoleão Bonaparte, são apropriados ao bel prazer de uma conveniência particular e privada. O pesquisador paulista Sérgio de Carvalho na Apresentação de Teoria do Drama Burguês [Século XVIII] (Cosac Naify, 2004) nos esclarece essa questão, quando diz que para Peter Szondi o

projeto crítico era compreender as razões pelas quais a dramaturgia' desde o Renascimento' veio a es treitar o campo de imaginação do palco - antes aberto aos amplos espaços públicos e gestos coletivos - nas dimensões da família patriarcal' concebida como o lugar da felicidade possível 'o que duraria até a época naturalista da crise do drama' quando o paraíso da intimidade do lar torna'se o inferno). (...) O drama burguês' neste aspecto' se define como o gênero por excelência da ideologia privatista' a forma teatral soberana da representação de uma nova sociabilidade que valoriza o mundo privado separado do público e que torna as peças "documentos de uma identidade permanente". "CARVAL$H O$, 2004, $p^{.12-3)}$

Diante disso, percebe-se que o Drama foi - e ainda é - inegavelmente um elemento fundamental na vida do longevo Teatro Ocidental, ora exercendo certa primazia, outrora incitando uma crise e se encerrando num espectro fantasmagórico ${ }^{6}$. Logo, concluída essa fugaz incursão histórica, a silenciamos, a fim de coçar outra pulga mais furiosa e inquietante: qual o âmbito do texto no teatro contemporâneo?

Quando nos vem à superfície essa questão, surgem ainda várias outras indagações. Qual a função do texto no teatro? O teatro prescinde do texto? No teatro "sem-texto" há texto? Ademais, a dramaturga e pesquisadora alemã Theresia Birkenhauer, nos acrescenta algumas outras dúvidas.

O que se coloca em questão não é somente a autonomia literária do drama frente a uma prática de escrita a partir dos processos cênicos e junto a eles 'ou seja' aproveitando uma pergunta de Sarah Kane: "Será que o teatro é mais exigente que as peças?"), mas também o lugar e a função do texto no teatro. Como se deve denominar aquilo que não é mais claramente um texto de personagem? Fala

\footnotetext{
5 Acerca dessa relação entre autoria e poder ver FOUCALT, Michel. O que é um Autor? In Estética: Literatura e Pintura, Música e Cinema. Rio de Jáneiro: Forense Universitária, 2006.

6 Sobre essa "fantasmagoria" do gênero dramático diante da escrita teatral ver a obra O Futuro do Drama (Ed. Campo das Letras, 2002), na qual o professor francês Jean-Pierre Sarrazac nos esclarece acerca da presença de elementos de ordem dramática na dramaturgia contemporânea. Para ele o Drama não é mais soberano, mas sim progenitor de diversos componentes textuais que se hibridizam na textualidade cênica, em fricção com tantos outros, de ordem épica, lírica e etc.
} 
teatral' corpo verbal' verbo' poesia? (BIRKENHAUER, ${ }^{2012,} p^{4)}$

Assim sendo, deparamo-nos com outro status quo - sucedendo os citados anteriormente - do texto no teatro atual, e observamos um trânsito em devir. E assim como quem tem os pés firmados no olho do furacão, observamos a palavra lançar-se em diversos e múltiplos caminhos, que ao sabor do vórtice impetuoso, cruzamse e se contaminam, e buscam um mesmo objetivo: a efetivação do verbo no instante performativo da cena, a fim de realizar uma concreta e legítima realização cênica de sua materialidade textual.

Essas são questões demasiado complexas e infinitas, e, além disso, particulares de nosso tempo histórico, uma vez que vimos a partir da segunda metade do século XX e na primeira década do XXI, manifestações teatrais que se recusam abertamente a utilizar o texto, e investem sistematicamente na experimentação físicocorporal e no arranjo e produção de imagens concretas, procedimentos derivados certamente da Performance.

Entretanto' se há uma arte que se beneficiou das aquisições da performance' é certamente o teatro' dado que ele adotou alguns dos elementos fundadores que abalaram o gênero 'transformação do ator em performer descrição dos acontecimentos da ação cênica em detrimento da representação ou de um jogo de ilusão' espetáculo centrado na imagem e na ação e não mais sobre o texto [‥]· Todos esses elementos que inscrevem uma performatividade cênica. (FÉRAL, ${ }^{2008,} p^{198)}$

Entretanto, a tradição textual referente à prática cênica ocidental não se resume somente à representação dramática oriunda da sociedade burguesa oitocentista, e abarca também atitudes e intervenções públicas e populares. Para tal, basta arrebatarmos da nossa memória dois instantes: as Tragédias Gregas e as dramaturgias de William Shakespeare (1564-1616). Tais produções são permeadas de fino trato com a produção formal, ou seja, atêm-se em cadências, ritmos e métricas, o que, talvez pela tradição da Razão, ofuscou-se na constelação histórica. Porém, tal negligência diante da potência formal dessas produções não foi capaz de obscurecer a maestria de gênios como Sófocles ( 496 a.C-406 a.C), Eurípedes (480 a.C-406 a.C) e Shakespeare, e não é raro ouvirmos cotidianamente alguns comentários tais como: quanta poesia em Romeu e Julieta!; como soa bem os versos de Medéia!; Édipo parece música aos ouvidos!. Nesse sentido, Birkenhauer tem dizeres que complementam nosso argumento.

Libertado da polifuncionalidade fundamental da comunicação cotidiana' ou seja' da comunicação puramente referencial de informações' a linguagem no texto teatral pode ativar preferencialmente a função poética de seus signos. (...) As teorias mais recentes do drama também atestam aos textos teatrais um "uso poético da linguagem", no sentido de que eles não se definem pelo representado' mas se referem ao seu próprio acabamento formal e ao processo teatral da representação e da percepção. (BIRKENHAUER, ${ }^{2012,} p^{.182)}$

Nessa esteira, - ou seja, de textos aparentemente "não-dramáticos" do ponto de vista do drama burguês - textos teatrais mais recentes como os de Maurice Maeterlinck (1862-1949), Gertrude Stein (1874-1946), Heiner Muller (1929-1995), Bernard-Marie Koltès (1948-1989), Sarah Kane (1971-1999) e Valère Novarina (1947), se revelam diante de nós não como diálogos intersubjetivos de cunho familiar e dramático, que possuem apenas uma função meramente intraficcional comunicativa, mas sim como falas articuladas poeticamente, que exploram os potenciais sonoros e rítmicos, e acima de tudo, a imaginação e o lúdico, através de metáforas bem orquestradas. Assim, tais textos ampliam o sentido de um uso poético da linguagem, projeto iniciado por dramaturgos da Antiguidade e do Renascimento, suspenso no Drama Burguês, instigado na Crise do Drama ${ }^{7}$ e radicalizado a partir da segunda metade do século XIX.

(...) as práticas de escrita realizadas por autores europeus a partir dos anos ${ }^{60} e^{70,}$, como' por exemplo' Peter Handke' Michel Vinaver' e posteriormente Heiner Müller e Bernard'Marie Koltès [sic] nos anos ${ }^{80}$, já não condizem com os princípios formais dessa dramaturgia [dramática] ${ }^{8} \cdot$ Esses autores difundiram uma escrita teatral que solapa os fundamentos do drama e coloca em questão os princí pios da mimese realista. A crise dessa mimese se tornou visível também no Brasil ainda durante a ditadura militar e antes da queda do muro de Berlin' evidenciando que na base dela está não só o fim 7 Acerca da Crise do Drama ver SZONDI, Peter. Teoria do Drama Moderno (1880-1950). São Paulo: Cosac Naify, 2011. 
das grandes narrativas de libertação' mas também o modo como as novas tecnologias são introduzi' das pelo capital nas sociedades contemporâneas. (BAUMGÄRTEL, ${ }^{2011,} p^{\cdot 2)}$

Assim sendo, é notório como textos da envergadura de O Interior (Maeterlinck), Hamlet-Máquina (Muller) e O Animal do Tempo (Novarina), são fabricados por mãos que acima de tudo privilegiam não somente as potencialidades do texto, mas, sobretudo da fala, através da manipulação de sonoridades, prosódias, cadências, polissemias e sintaxes.

\begin{abstract}
De fato' a crise do drama enquanto forma teatral fez com que alguns dramaturgos brasileiros começaram [sic] a experimentar com formatos prédramáticos 'o Auto' a missa' o mistério' ou nãodramáticos 'a peça monológica' a peça simbolista' a peça paisagem' introduzindo no formato do drama elementos alheios à estética representacional realista do drama' como por exemplo' o fan' tástico e o surreal com suas transformações dos eixos temporais e locais da ação' e mais importante ainda' utilizando uma linguagem poetizada ou até jogos de linguagem. Estamos perante uma busca dramatúrgica que tenta substituir a lógica do realismo burguês não só por uma lógica não'realista' mas por uma escrita com uma multiplicidade de centros. (BAUMGÄRTEL, ${ }^{2011}, p^{.3)}$
\end{abstract}

Por outro lado, ainda há um fantasma um tanto quanto "conservador", que ronda os textos teatrais contemporâneos e recorrentemente insiste em questionar as qualificações literárias de um texto, que, obviamente, foi feito para fins não necessariamente literários, ou seja, o teatro, ou melhor, à materialidade cênica. Nesse sentido, tem sido recorrente o aproveitamento cênico de textos estrangeiros ao gênero dramático, assim como romances, contos, poemas, matérias de jornal, depoimentos e afins. Desta forma, é evidente que não se deve mais aplicar sobre os textos teatrais contemporâneos o velho pente dotado de cerdas aristotélicas, ou a antiga peneira da obra bem-feita. A prática cênica contemporânea não mais se relaciona com a palavra de maneira hierarquizada, mas sim em torno de um processo fágico, no qual as funções teatrais (dramaturgia, encenação, atuação, iluminação, cenografia) envolvidas na criação cênica apropriam-se de materiais textuais diversos e a partir disso compõem suas textualidades. Esse processo origina certamente uma textura cênica híbrida e heterogênea, devido à multiplicidade de materiais de ordem distintas, envolvidos no fazer teatral de maneira justaposta.

O velho juízo que afirmava que um texto é "inapto para o palco" não é mais válido· Hoje em dia' não existem mais textos que seriam "impossíveis de serem apresentados no palco" por causa de car acterísticas específicas de seu gênero ou de sua forma. Textos em prosa' romances' epopeias' poemas' radiodramas: todo tipo de texto está sendo 'realizado' no palco' sem passar por uma 'dramatização' no sentido usuário - o Velho Testamento bem como o bestseller da última temporada' roteiros de filmes ou textos de autores famosos que não foram escritos para o palco. Os textos teatrais recentes não podem mais ser classificados por meio das características tipológicas do drama' nem por respeit ${ }^{-}$ ar estruturas dialógicas' nem por seguir outros elementos formais deste. Frente a essa prática teatral contemporânea' a questão sobre se o teatro precisa do texto ou deveria prescindir dele para libertar a sua própria característica artística' que era uma polêmica na época das vanguardas teatrais' não constitui mais uma alternativa antitética. Parece que o velho conflito entre teatro e literatura chegou ao fim. Mesmo as tradicionais fronteiras culturais' que por muito tempo propiciaram uma orientação' 'que o teatro do texto seja o teatro institucional' concebendo"se como instituição da formação literária' enquanto o teatro experimental seja "antiliterário" ou "além do texto" não servem mais. (BIRKENHAUER, ${ }^{2012,} p^{\text {. 182) }}$

Portanto, o que testemunhamos surgir na atualidade - referindo-se também a experiências do derradeiro século - é uma ressignificação da função formal do texto dentro da realidade teatral, e não cabe mais ao dramaturgo - ou melhor, ao escritor teatral - articular conteúdos de maneira delimitada a priori, advinda de uma determinada convenção ou dogma.

Dessa maneira, vemos desabrochar uma prática de escrita que prima pelo agenciamento de dois eixos primordiais: (1) a articulação e arranjo dos elementos que compõem a linguagem, e a própria (2) prática do teatro. Nesse sentido, trata-se de um texto que enfatiza a materialidade cênica e a recepção do espectador, ou seja, 
a performatividade teatral. Nesse sentido, o escritor teatral contemporâneo funciona como um produtor de formas textuais sui generis, que combinam e coordenam os múltiplos modos de variação da palavra, do verbo e da fala, a fim de proporcionar uma experiência singular e empírica ao espectador, que se vê realizada exclusivamente no presente da cena. Assim, surge um distinto processo de fruição perante a textualidade cênica, um projeto viabilizado na sua condição enquanto provocação de chaves de leitura originais e múltiplas, pois não há uma única e certa possibilidade de leitura.

O primeiro procedimento é servir`se da materialidade do significante verbal: evidenciar ritmo', prosódia' musicalidade ou sonoridade do texto falado' elementos onomatopoéticos' mas também a morfologia e a sintaxe enquanto aspectos desta materialidade' etc Ou seja' trata'se de uma tenta tiva de focalizar criticamente os processos de significação no interior da língua' dissolver a certeza epistemológica da representação linguística no jogo da materialidade da fala $O$ segundo consiste em focalizar criticamente os processos de significação na mente do usuário; em realçar a construção desta certeza como efeito de uma pressão exercida por determinado contexto sócio-histórico; em posicionar o texto falado numa fronteira constituída pelo uso ou pela citação desviante de processos sociais de significação. (BAUMGÄRTEL, ${ }^{2010,} p^{\text {. 122) }}$

Diante disso, com o objetivo de exemplificar a argumentação que até aqui desenvolvemos, utilizar-se-á uma encenação e uma dramaturgia pertencente ao contexto teatral brasileiro contemporâneo, tendo como critério a potência performativa das palavras. Para tal convoca-se o espetáculo Congresso Internacional do Medo, realizado pelo grupo Espanca! ${ }^{9}$, obra dirigida e escrita pela ex-integrante Grace Passô. Ademais, tal grupo dialoga diretamente com as conjunturas coletivas mencionadas anteriormente (teatros de grupo).

Primeiramente deve-se ressaltar o fato de que no caso do Congresso, a feitura do texto e da cena foram feitas simultaneamente, o que implica certamente em mútuas colaborações e contaminações entre estas duas instâncias - caso fôssemos pensá-las dicotomicamente, o que talvez seja incoerente nesse caso.

Dessa maneira, há um primeiro fator que se mostra imprescindível para uma produção formal da dramaturgia, e consequentemente, da textualidade cênica: a dimensão temática. $O$ fato de a estrutura do espetáculo concentrar-se numa situação expositiva, ou seja, de um Congresso, leva a um resultante inerente: a comunicação objetiva e extraficcional. Quer dizer-se com isso que a escolha dos artistas por uma estrutura de congresso anula inevitavelmente a forma dramática tradicional, calcada em relações intersubjetivas e na representação de uma realidade intraficcional. Logo, "essa dimensão temática é fundamental para salvar o texto e a montagem de um mero jogo formal privado” (BAUMG̈̈RTEL, 2012, p. 146).

Além disso, o texto em nenhum momento se propõe a ser uma história contada, ou seja, uma ficção, mas se configura como um acontecimento, no sentido de ser um evento no qual a princípio não é comum que aconteça qualquer fato trágico ou drama familiar. Assim, novamente o conteúdo transpõe-se em forma, e viceversa, processo que assinala justamente o que Szondi caracterizou como sendo a faísca para a Crise do Drama: a relação hegeliana entre forma e conteúdo.

Assim sendo, partimos a outra instância: os mecanismos utilizados pela dramaturga - em colaboração com os atores - capazes de dar conta dessa instância temática. Para isso, devemos nos questionar acerca do motivo pela escolha dessa estrutura. Todavia, melhor do que instalar aqui respostas conclusivas, busca-se acima de tudo propor possibilidades, e sobre elas traçar os elementos de construção dramatúrgica que dialogam diretamente com a cena. Além disso, nossa intenção aqui em nenhum momento é solucionar o discurso ou o tema da obra - se é que há como realizar isso -, mas sim analisar sua configuração, sua fisionomia, assim como um médico que disseca um cadáver em busca dos princípios moleculares e constitutivos do corpo findo. Ou seja, nos interessa os modos de composição e os procedimentos de fabricação do Congresso.

Assim sendo, num primeiro instante parece haver uma reinvindicação sócio-política no argumento da obra, alicerçada no fato de que não é raro nos depararmos contemporaneamente com congressos que se resumem a uma comunicação tempestiva e caótica, na qual não se entende nada do que é falado, ou seja, falam sem nada dizer. Como apoio a essa nossa possibilidade, têm-se Novarina:

Eis que agora os homens trocam entre si palavras como se fossem ídolos invisiveis' forjando nelas apenas uma moeda: acabaremos um dia mudos de tanto comunicar; nos tornaremos enfim iguais aos $9 \quad$ Sediado em Belo Horizonte (MG), o Espanca! foi fundando em 2004 e desde entấo concebe projetos que movem dinamicamente sua linguagem e expandem a relação do coletivo com o teatro (PASSÔ, 2012, p. 71). 
animais' pois os animais nunca falaram mas sempre comunicaram muito'muito bem Só o mistério de falar nos separava deles. No final' nos tornaremos animais: domados pelas imagens' emburrecidos pela troca de tudo' regredidos a comedores do mundo e a matéria para a morte O fim da história é sem fala. (NOVARINA, ${ }^{2009,} p \cdot{ }^{13)}$

Ademais, há uma fala da Tradutora que nos esclarece:

Tradutora: 'sussurra' Esse definitivamente é o último congresso em que trabalho Esses congressos me cansam e vou dizer mais claramente o que eu acho' eu acho que eles me chamam porque é mais barato chamar uma tradutora poliglota do que uma tradutora que fala uma língua só. E eu também me enervo quando dá algum problema e eles olham pra mim' como se eu não tivesse sido convidada também. Quando eles chegaram aqui. vieram me perguntando uma série de coisas sobre o evento como se eu o tivesse organizado. Quando eles falaram agora' que não sabiam o motivo de estarem aqui' me [sic] deu vontade de tomar a palavra e dizer que eu também não sei por que estou aqui. Que eu também me prometi descansar desse trabalho com as palavras. As palavras me cansam. E' sabe' nem tudo é possivel traduzir Quando eu olho algum palestrante que' por algum momento' não sabe bem o que diz' eu acho tão mais significativo do que sair por aí dizendo palavras e palavras tentando nomear algum conceito. Eu conheço esse tipo de evento. Eles ficarão horas e horas tentando conceituar a vida e quando chegarem em suas casas' em seu país" não vão conseguir sequer dizer "boa noite" para alguém de quem sentem mágoa" não sei por quanto tempo ainda ficaremos aqui. (PASSÔ, 2012, $p^{\text {25) }}$

Nesse sentido, ou seja, da incomunicabilidade, há algo para ser evidenciado: todos os convidados do Congresso são falantes de uma língua "estrangeira" ao português, exceto os índios Trumak e Payá. Logo, presume-se que a efetivação da comunicabilidade - ou não - é uma questão latente no discurso cênico proposto. Todavia, mesmo que exista uma tradutora dentre os personagens, nada nos garante que a tradução é realmente o que eles dizem, uma vez que as línguas que todos eles falam são "desconhecidas", parecidas com o que muitos criadores teatrais conhecem por grammelot.
Na língua de Sra: Reluma: (0)
Tradução em português: Toda mulher carrega o mundo dentro de si.
Na lingua de Sra. Reluma: $|\backslash| / / \_\backslash|| \mid \_\backslash \backslash \backslash$
Tradução em português: O mundo carrega mal as mulheres.
$\mathrm{Na}$ língua de Sra Reluma: ${ }^{\circ 0} \mathrm{OO}^{\circ} \mathrm{O}^{\circ} \mathrm{OO}^{\circ} \mathrm{OoO}^{\circ \mathrm{o}}$
Tradução em português: Pergunte às cegonhas' para você entender. (PASSÔ, ${ }^{2012,} p^{17)}$

Portanto, o que vemos nesse procedimento é a materialização formal e cênica da própria intenção do texto: questionar a comunicação, a fala, a língua. Para tal, a dramaturga não se ateve a se adequar a formas préestabelecidas, convencionais e testadas anteriormente; sua tarefa se revela justamente no processo de experimentação da língua, no objetivo de materializar textual e cenicamente o discurso dos artistas ali envolvidos. Assim, como dito anteriormente aqui, a sua produção mostra-se sui generis, na medida em que é originária de uma condição singular, única.

O que é próprio ao teatro não é nem uma relação específica nem determinados modos de falar. Ele é um lugar de experiências com a língua totalmente diferente. Seja esta experiência a da língua enquanto mascaramento' enquanto transgressão de retóricas' enquanto ambiguidade das palavras' enquanto extinção de significado' enquanto violência da fala ou polissemia das expressões verbais. Conforme isso' a gama da imaginação literária no teatro está se ampliando A língua aparece em formas que não podem mais ser relacionadas a convenções dramáticas. Textos aparecem como tessitura de infinitas formas de fala e de língua' que abrangem distintos horizontes ficcionais e não-ficcionais. (BIRKENHAUER, ${ }^{2012,} p^{\text {14) }}$ 
Além do mais, há outra personagem na dramaturgia de Passô que implica diretamente nessa textualidade performativa aqui tratada: o Sr. Doutor José. Tal personagem é a que talvez mais questione a pernosticidade e o pedantismo de algumas célebres figuras envolvidas nos corriqueiros congressos das diversas áreas do conhecimento acadêmico. Isso se dá no fato de que todas as falas dessa personagem são feitas na língua portuguesa, entretanto, numa construção puramente poética e metafórica - diferentemente da linguagem utilizada por alguns acadêmicos. Tal processo potencializa-se ainda mais devido a atitude da Tradutora, que insiste em transpor a fala do Sr. Doutor José para um português formal e técnico.

Doutor José: 'com um pequeno globo terrestre nas mãos' '...Assim como o senhor também libertou' digo aos presentes que igualmente fago o fato desse.

Tradutora: 'traduzindo Doutor José) Assim como disse o senhor' gostaria de dizer para a plateia presente que fui convidado da mesma forma que ele para este encontro.

Doutor José: (pega uma carta' Pousava no meu teto até chegar este papel com meu nome; dentro dormiam as seguintes palavras...

Tradutora: 'traduzindo Doutor José) Estava em casa' quando recebi esta carta endereçada a mim' com os seguintes dizeres."

Doutor José: lendo a carta) "Você me dê licença".

Tradutora: (traduzindo Doutor José) Caro senhor

Doutor José: "Opa!"

Tradutora: 'traduzindo Doutor José) Saudações!

Doutor José: "Desejamos tirar a roupa querendo gritar sussurrando ao seu ouvido' para que esteja aqui no Congresso internacional do Medo".

Tradutora: 'traduzindo Doutor José' É com satisfação que vimos através desta convidálo para integrar a mesa do Congresso Internacional do Medo.

Doutor José: "Ao senhor, dizemos que muito queríamos sentir o cheiro de seu atraente corpo".

Tradutora: 'traduzindo Doutor José) Ao habitante desta ilha' reiteramos nosso profundo interesse em ter seu pensamento permeando nossas cabeças' a fim de que elas se embebedem das suas palavras.

Doutor José: "Para poder tocá-lo oferecemos o testículo de uma mão de ficções".

Tradutora: 'traduzindo Doutor José) Para sua participação' o evento oferece' como agradecimento por sua nobre presença' a importância simbólica de cinco ficções.

Doutor José: Aí povoei a alma:

Tradutora: 'traduzindo Doutor José' Então eu pensei:

Doutor José: É uma mão de ficções compra muita coisa.

(PASSÔ, 2012, $p^{\text {19-21) }}$

Outra característica performativa do texto na encenação de Congresso, é o fato de no início haver a projeção da descrição de cada personagem-convidado. Dessa maneira, o texto que antes estava reservado ao papel, e em último caso, à boca dos atores, expande suas plataformas, seus suportes, e é transposto para a materialidade cênica de uma maneira visual, e não se restringe a maneira usual, ou seja, o viés sonoro.

Sr-Doutor José

Habitante de uma pequena ilha inicialmente situada em meio ao oceano Atlântico' mas que inexplicavelmente passou a se locomover livremente pelos oceanos. A ilha' que não possui localização fixa no mapa e perambula pelos dois hemisférios da Terra' é falante de uma língua ainda indecifrada' uma espécie de português ás avessas: [”]

Sr. Tusgavo Tapbista

Estudioso de peixes representante de Nhanpenha' país conhecido pela famosa "galinhada", festa em que homens atraem as galinhas com um pano' e quando essas se aproximam são espetadas com pequenas varas cortantes. Um dia' Nhanpenha foi colonizada pela Espanha e hoje o país é falante de uma lingua cujo som se assemelha ao espanhol [ [..]

Sra. Reluma Divarg

Estudiosa do medo nos contos de fadas infantis'Sra' Reluma esta coberta por longos panos' e dela só 
é possivel ver os olhos Habitante da República da Mínia' país falante de uma língua que soa como a harmonia de uma música [ [-]

Trumak e Payá

Representantes dos Ayritã' povo que nos primeiros registros somavam ${ }^{150}$ mil habitantes em terras brasileiras e hoje só existem dois' apenas: Trumak e Payá [].

Além do mais, o texto que é projetado não se adequa ao que é tradicionalmente conhecido como texto teatral, ou seja, um diálogo intersubjetivo no presente. Sua composição é puramente épica, no seu sentido descritivo e analítico, provinda de alguém que não somente conhece todas as personagens, mas consequentemente toda a história. Nesse sentido, a figura do dramaturgo, que antes era oculta no texto teatral - revelada apenas através de didascálias e afins -, e inquestionavelmente extinta da materialidade da cena, passa a se fazer presente na concepção do próprio espetáculo. Dessa forma, as palavras de Congresso criam espaços outros na encenação, e não se restringe apenas a comunicação sonora.

A encenação realiza uma dimensão da língua que se livra da função descritiva e comunicativa da fala dramática. Ela gera novos espaços de significação' de modo que a língua não é mais somente parte funcional da narrativa dramática' mas desenvolve um movimento próprio' que por sua vez transforma o acontecimento cênico Desse modo' a encenação possibilita uma transformação e uma modelagem da fala teatral e com isso uma prática da linguagem própria do teatro. 'BIRKENHAUER, ${ }^{2012,} p^{186)}$

Diante disso percebe-se que o texto, na esteira das mudanças vividas pelo teatro nas últimas décadas, vem se inserindo de maneira a compor junto e com a cena, diferentemente do que ocorria antes nos processos hierarquizados - fato esse ressaltado pelas produções de dramaturgos em processos colaborativos ${ }^{10}$.

Logo, sendo o espetáculo Congresso Internacional do Medo derivado de uma experiência colaborativa e em consonância com a contemporaneidade teatral, é evidente a existência dessa materialização cênica da palavra na encenação, por meio não somente da projeção dos textos citados, mas também da interferência que o grammelot e o delay, advindo da tradução, causam no tempo-espaço da cena.

A procura de novas possibilidades teatrais extrapola o simples objetivo de mimese da realidade, não se justificando mais a elaboração da intriga' do diálogo' das personagens completas nem de um espaço cênico à italiana. (...) Essa característica' essa manifestação cênica no teatro atual começa a ser compreendida e levada em conta pela dramaturgia na hora de se elaborar um texto ou uma estrutura dramática. Textos que em vez de ser um empecilho 'pela sua estrutura racionalista' são uma motivação para uma poética performática em cena' introduzindo elementos de estrutura de ação dentro de um código poético diferente (...) O texto é mais um recurso' entre os outros da representação' que tem também importância para um processo de encenação mais sensivel. Nesse sentido' a dramaturgia procura se renovar e dar conta das novas inquietações expressas pelos criadores da arte cênica que não querem depender mais do autor nem de um texto preestabelecido para fazer um espetáculo sur gir ${ }^{(. . .)}$Eles [dramaturgos] ${ }^{11}$ incorporam' na estrutura dramática do texto' as inquietações manifestadas por artistas que decidiram trabalhar sem um autor nem com uma dramaturgia convencionada Ou seja' um novo tipo de texto dramático está estruturado de tal maneira que ele consegue propiciar o acontecimento performático' ritualista' além de acentuar a exploração do impacto do tempo presente na ação a ser desenvolvida em cena. (RAMIREZ, ${ }^{2013,} p^{\text {. }}{ }^{46)}$

Dessa forma, a relação do texto com a cena que antes se restringia a "perfeita tradução cênica do universo simbólico do autor com seu espírito e com sua arte” (TORRES, 2001, p. 68), se transforma em criação e composição compartilhada, numa mútua colaboração entre as diversas instâncias do espetáculo, a saber, o cenário, a interpretação, a iluminação e as outras demais.

\footnotetext{
10 Para saber mais sobre a atuação de dramaturgos em processos colaborativos ver NICOLETE ABREU, Adélia Maria. Da Cena ao Texto: dramaturgia em processo colaborativo. 2005. Dissertação (Mestrado em Artes Cênicas) - Escola de Comunicações e Artes, Universidade de São Paulo; e ARY, Rafael Luiz Marques. A função dramaturgia no processo colaborativo. 2001. Dissertação (Mestrado em Artes) - Instituto de Artes, Universidade de Campinas.

11 Inserção nossa.
} 
Uma encenação não é classificada como leitura por acentuar o conteúdo de textos de modos diversos - o que se associa com o "teatro dos diretores" dos anos ${ }^{70}$ - mas por organizar os textos cenicamente' para' dessa forma' "restaurar um determinado uso' mais abrangente e mais radical' da palavra"" Se analisarmos os procedimentos de encenação que geram essa dimensão da linguagem' perceberemos que realizam potenciais cênicos genuínos do palco Os procedimentos são dos mais diversos: um deslocamento do sentido das palavras pela imagem' um modo específico de atuação' formas de espacialização da palavra' criação de temporalidades heterogêneas. Entretanto' esses deslocamentos sempre impactam sobre a língua' colocam"na "em cena" de forma diversa. 'BIRKENHAUER, ${ }^{2012, ~} p$. 187)

À vista disso, é palpável e latente o processo de "performatização" do texto em relação com a cena, e uma vez esse processo consolidado, alcançaríamos a plena realização verbal almejada por grande parte das dramaturgias contemporâneas. Para tal, é necessário, também, que atores e outros artistas compreendam esse decurso pelo qual vem passando o texto teatral, e que, uma vez minimamente percebida tal alteração pragmática nos fundamentos da escrita teatral, possam corroborar para sua (re)construção, suscitando novas questões e desequilíbrios: outras possibilidades a ser; pois, - novamente - assim como a morte, é certo que temos os pés firmados num cosmo que é prazeroso ritornelo. E a tanto, de qualquer forma, ou de nenhuma outra, o homem sempre h(á)ouve de diz(er): "Eu sou aquele para quem a palavra é a única coisa que me resta para falar" (NOVARINA, 2007, p. 14). E, para começar esse nosso texto, citamos:

Homem de Buraco Charivari' que carne te pegou' malensinado? Por que você sabe todas essa palavras? Foi você mesmo que te encontrou e te apanhou de tão baixo? Que dizem eles? Quando se vê o que se vê' quando se sabe o que sabe' se tem razão de pensar o que se pensa. Quando se diz o que diz' e assim faz e assim diz' acrescentar o quê? Se eu vejo o que percebo' fiz essa viagem com gracejo A carne' por que será que ela tomou a aparências das palavras? De onde vem que se fala? Que a carne se exprime? NÃO CABE AOS ANIMAIS FALAR DISSO .12 (NOVARINA, 2007, $p$. ${ }^{30}$

\section{Referências}

ARAÚJO, Antônio. A encenação no coletivo: desterritorializações da função do diretor no processo colaborativo (tese de doutorado). São Paulo: Universidade de São Paulo, 2008.

ARY, Rafael Luiz Marques. A função dramaturgia no processo colaborativo. 2001. Dissertação (Mestrado em Artes) - Instituto de Artes, Universidade de Campinas.

BAUMGÄRTEL, Stephan. O sujeito da língua sujeito à língua: reflexões sobre a dramaturgia performativa contemporânea. Revista VIS (UnB), v. 9, 2010, p. 107-124.

. Meta-textualidade, instâncias de enunciação e conflitos não-narrativos - re-

flexões sobre impulsos não-dramáticos na dramaturgia brasileira contemporânea. Revista Urdimento

(UDESC), v. 18, 2012, p. 141-154.

. Estratégias de escrita teatral não-dramáticas e a oficina de dramaturgia no con-

texto contemporâneo: algumas reflexões preliminares. Revista O Teatro Transcendente (FURB), v. 16, 2011, p. 02-11.

BIRKENHAUER, Theresia. O tempo do texto no teatro. Revista Cena (UFRGS), v. 11, 2012, p. 1-15.

. Entre fala e língua, drama e texto: reflexões acerca de uma discussão contem-

porânea. Revista Urdimento (UDESC), v. 18, 2012, p. 181-188.

CARVALHO, Sérgio de Carvalho. Apresentação In: Teoria do Drama Moderno (1880-1950). São Paulo: Cosac

Naify, 2011.

DELEUZE, Gilles. Clínica e Clítica. São Paulo: Ed. 34, 1997.

. Acerca do Ritornelo In: Mil platôs - capitalismo e esquizofrenia, vol. 4. São Paulo: Ed. 34,

1997.

FÉRAL, Josette. Por uma poética da performatividade: o teatro performativo. Revista Sala Preta (USP), v. 8, 2008.

FERNANDES, Silvia. Grupos teatrais - anos 70. Campinas: Editora da Unicamp, 2000.

12 Grifo nosso. 
FOUCALT, Michel. O que é um Autor? In Estética: Literatura e Pintura, Música e Cinema. Rio de Janeiro: Forense Universitária, 2006.

NICOLETE ABREU, Adélia Maria. Da Cena ao Texto: dramaturgia em processo colaborativo. 2005. Dissertação (Mestrado em Artes Cênicas) - Escola de Comunicações e Artes, Universidade de São Paulo.

NOVARINA, Valère. Discurso aos animais (O animal do tempo e A inquietude). Rio de Janeiro: Ed. 7 Letras, 2007.

Diante da Palavra. Rio de Janeiro: Ed. 7 Letras, 2009.

OLIVEIRA, Valéria Maria de. Reflexões sobre a noção de teatro de grupo. 2005. Dissertação (Mestrado em Teatro) - Universidade do Estado de Santa Catarina.

OLIVEIRA, Pedro Rocha de. Arte e sociedade burguesa na teoria do texto teatral de Peter Szondi. Revista Crítica Cultural (Unisul), v. 8, n. 1, 2013, p. 11-26.

PASSÔ, Grace. Congresso Internacional do Medo. Rio de Janeiro: Ed. Cobogó, 2012.

RAMIREZ, José Manuel Lázaro de Ortecho. Dramaturgia na pós-modernidade: aspectos performáticos da escrita cênica contemporânea. Revista Rebento (UNESP), v. 4, 2013, p. 43-49.

ROUBINE, Jean-Jacques. A linguagem da encenação teatral. Rio de Janeiro: Zahar Editores, 1982.

SARRAZAC, Jean-Pierre. O Futuro do Drama. Porto: Ed. Campo das Letras, 2002.

SCHETTINI, Roberto Ives Abreu. O teatro como a arte do encontro: dramaturgia da sala de ensaio, uma abordagem metodológica para a composição do espetáculo "gennesius Histriônica epopéia de um martírio em flor” junto ao grupo finos trapos. 2009. Dissertação (Mestre em Artes Cênicas) - Escola de Teatro e Escola de Dança, Universidade Federal da Bahia.

SZONDI, Peter. Teoria do Drama Moderno (1880-1950). São Paulo: Cosac Naify, 2011.

TORRES, Walter Lima. Introdução histórica: o ensaiador, o diretor e o encenador. Revista Folhetim, v. 9, 2001, p. 61-71. 